\title{
Introduction
}

\section{Money Matters: Individuals, Communities and Everyday Economic Interactions between Jews and Christians in Medieval Europe}

This special issue of Medieval Encounters offers new perspectives for studying the activities and the roles of Jews in the medieval economy. ${ }^{1}$ Scholarship to date has tended to approach these subjects from a communal perspective, discussing the activities of Jews as an organized group rather than as individuals, and emphasizing collective norms, legislation, ideologies, and policies. In such studies, the status of Jews as a tolerated religious minority was the point of departure and religious difference was paramount. ${ }^{2}$ While these perspectives were undoubtedly a defining feature of medieval Jewish life, a top-down communal perspective is just one facet, albeit an important one, of the economic activities of medieval Jews. In addition, most studies focused on moments of change, tension, and crisis, rather than on the ongoing roles of Jews both within their communities and in interaction with their Christian neighbors.

This collection of articles looks at the Jews' everyday economic interactions, primarily with Christians, shining a particular light on the choices and

1 This volume originated in a conference held in Jerusalem in Dec. 2019. Some of the papers were reworked and appear here in revised form. My thanks to all the contributors to this volume, and particularly to Nureet Dermer, Aviya Doron, and Andreas Lehnertz who helped plan and organize the original conference and commented on this introduction. A special, additional, thanks to Nureet Dermer and Aviya Doron who also accompanied the process of preparing this collection. Thanks as well to Judah Galinsky, Daniel Lord Smail, Ryan Szpiech, and the anonymous reviewer of the journal for their comments and suggestions on this piece. The publication of the entire volume, including this article, was supported by the European Research Council (ERC) under the European Union's Horizon 2020 research and innovation programme (grant agreement No 681507).

2 These issues are discussed at length below. 
activities undertaken by individuals in the framework of their daily lives. ${ }^{3}$ All the articles seek to answer questions such as how did individual Jews interact with communal and urban authorities, what choices did they make, and what can we learn about their modes of doing business? A second shared feature of all the articles in this collection is the emphasis on the constant interaction between Jews and non-Jews. Each article asks, in different ways, how the religious identity of the individuals in question determined the way business was conducted and what other factors, unrelated to religious identity, were at play. As the essays in this collection demonstrate, such distinctions are often complicated, as medieval Jews, like all medieval people, had multiple affinities and their activities were determined by a variety of factors.

Alongside the emphasis on individuals, the relationships between individuals and their specific religious communities, and between Jews and Christians, a third goal of these essays is to expand our knowledge and understanding of the roles Jews played in the medieval economy. One such role - the Jews as money lenders - has been the focus of the majority of research to date and was also at the heart of much of the legislation that has been studied. However, as the title of this essay suggests, this volume seeks to consider money more broadly. Put differently, there is more to money than the lending of it, and one of the aims of this collection is to illustrate some of the many ways Jews made and used money. As will become evident, this is no simple task given the types of evidence that have survived. In addition, the authors have sought to expand their focus from singular, one-time events to ongoing patterns of occurrence or, alternatively, to situate specific events within broader frameworks.

The articles in this volume cover many regions of Europe, including northern France (Dermer), England (Irwin), Germany (Lenhertz and Doron), Provence (Smail), and Iberia (Sapoznik), and this geography is indicative of a wide range of medieval European Jewish communities. Each essay addresses a specific situation or set of interactions but together they allow an overview of the different forms of financial and economic activities involving medieval Jews and the often competing interests of individuals and communities. The first three essays in the collection focus on individual cases: Nureet Dermer discusses two Jewish individuals who were caught by the authorities doing business with a Christian partner; Dean Irwin discusses one acknowledgement of debt from thirteenth century England and the way it illuminates the archae system,

3 For a survey of medieval Jewish daily life, see Norman Roth, Daily Life of the Jews in the Middle Ages, Greenwood Press "Daily Life through History" Series (Westport, Conn: Greenwood Press, 2005); Elisheva Baumgarten, Practicing Piety in Medieval Ashkenaz: Men, Women, and Everyday Religious Observance, Jewish Culture and Contexts (Philadelphia: Univ. of Pennsylvania Press, 2014); Ephraim Shoham-Steiner, Intricate Interfaith Networks in the Middle Ages. Quotidian Jewish-Christian Contacts (Turnhout: Brepols, 2016). 
the system of depositing documents in chests from this period; and Andreas Lehnertz discusses a partnership between a Jewish and Christian horn maker. The next set of essays looks at multiple interactions: Aviya Doron looks at cases revolving around pledges, which were pawns received in return for money lent to Christians by Jews; Daniel Lord Smail discusses the evidence of Jewish economic activities provided by notarial records and Alexandra Sapoznik focuses on the extensive trade of wax from North Africa to Europe.

This essay will highlight three aspects that emerge from the essays as whole: the choices and agency of individuals within their communities, the place and importance of religious identity within economic interactions and the importance of genre for historical analysis, relating, throughout, to the different essays in the collection.

\section{1 Choices, Communities, and Individuals}

A central assumption informing much of the research to date is that Jews were first and foremost members of their communities - especially since it was only within the community framework that Jews were allowed to settle in a particular location. ${ }^{4}$ This in turn has led to a focus on the community's fiscal obligations, such as those to local and regional frameworks, and thus on the financial contributions of individuals to their communities. As members of their community, for example, Jewish individuals were often subject to a variety of fees, often referred to as taxes in medieval sources. ${ }^{5}$ Some of these communal taxes were fixed whereas others fluctuated, as the communities were subject to special fees imposed specifically on Jews by local, regional, or royal authorities with little regularity or consistency according to the political and financial demands of the times. ${ }^{6}$

4 For surveys see Robert Chazan, The Jews of Medieval Western Christendom 1000-1500 (Cambridge: Cambridge University Press, 2006); and the recent collection of essays edited by Robert Chazan, The New Cambridge History of Judaism (Cambridge: Cambridge University Press, 2018), Vol. 6: The Middle Ages: The Christian World.

5 For a survey of some of these obligations in the context of Provence, see Ram Ben-Shalom, The Jews of Provence and Languedoc: Renaissance in the Shadow of the Church (Ra'anana: Open University Press, 2017), 50-98.

6 For examples see Robin R. Mundill, The King's Jews Money, Massacre and Exodus in Medieval England (London: Continuum, 2010); Robin R. Mundill, England's Jewish Solution: Experiment and Expulsion, 1262-129o (Cambridge: Cambridge University Press, 1998); William C. Jordan, The French Monarchy and the Jews: From Philip Augustus to the Last Capetians (Philadelphia: University of Pennsylvania Press, 1989), 64, 166-67, 173, 228-29, 233; Eberhard Isenmann, "Steuern und Abgaben", in Germania Judaica 3, 1350-1519, ed. Arye Maimon, Mordechai Breuer and Yaacov Gugenheim, (Tübingen: Mohr-Siebeck, 2003, 3: 2208-81; 
Communal penalties for those who did not contribute as obligated also varied depending on the case at hand and local circumstances. One of the tools used by the community to enforce compliance was the threat of excommunication. The underlying assumption of scholars has been that this was an effective threat with significant repercussions on the life of a targeted person and their family, and as such individual community members were willing to go to tremendous effort to avoid such bans. And indeed, many Hebrew sources describe a ban of excommunication that was a commonly used threat against those who did not adhere to communal instructions. ${ }^{7}$ In economic contexts, such a warning could be issued regarding the evasion of both internal taxes and those imposed by local or regional authorities. ${ }^{8}$

It is clear that the frequent mention of this threat should not be understood as synonymous with its power. To what extent is it reasonable to assume that the community provided such a degree of protection that individuals were willing to privilege its demands over and above their personal needs? After all, individuals first and foremost sought their own livelihood, for themselves and their families. Moreover, in many cases, each individual had to negotiate their right to reside in a certain place, in addition to the communal negotiations

Maike Lämmerhirt, Juden in den wettinischen Herrschaftsgebieten: Recht, Verwaltung und Wirtschaft im Spätmittelalter (Köln: Böhlau, 2007).

7 Examples of such penalties abound in responsa literature, for a few examples see: Isaac b. Moses, Sefer Or Zaru'a, ed. Shalom Klein (Jerusalem: Makhon Yerushalayim, 2008), \#115; Hilkhot shliah tzibbur; Simha of Vitry, Mahzor Vitry, ed. Simon Horowitz (Nürnberg: Mekize Nirdamim, 1898), \#575; Moses Parnas, Sefer Parnas (Vilna: Katzenelnbogen, 1891), \#359. Many times such bans were used to enforce tax collection but sometimes they had other purposes, for example, coercing a man to divorce his wife or perform levirate marriages. See for example R. Eliezer b. Joel haLevi, Sefer Ra'aviah, ed. David Deblytzki (Bnei Brak: D. Deblytzki, 2005), \#923. For studies of excommunication in Christian culture, see Sarah Hamilton, "Interpreting Diversity: Excommunication Rites in the Tenth and Eleventh Centuries," in Understanding Medieval Liturgy: Essays in Interpretation, ed. Helen Gittos and Sarah Hamilton (London: Routledge, Taylor \& Francis Group, 2017), 125-58; Véronique Beaulande-Barraud, Le malheur deetre exclu? Excommunication, réconciliation et société à la fin du Moyen âge, (Paris: Publications de la Sorbonne, 2006).

8 Such bans of excommunication are often mentioned in medieval Hebrew literature but have not been systematically investigated. They have been more thoroughly studied among Sephardim in early modern Europe, see Yosef Kaplan, An Alternative Path to Modernity: The Sephardi Diaspora in Western Europe (Leiden: Brill, 2000), 108-42 and 143-54. For the types of excommunication in medieval Ashkenaz, see Rainer Josef Barzen, ed., Taqqanot Qehillot Šum: die Rechtssatzungen der jüdischen Gemeinden Mainz, Worms und Speyer im hohen und späten Mittelalter (Wiesbaden: Harrassowitz, 2019), 1: 25-28; See also Simha Goldin, Uniqueness and Togetherness: The Enigma of the Survival of the Jews in the Middle Ages (Tel Aviv: HaKibbutz haMeuhad, 1997), $115^{-3} 6$ [Hebrew]. This is a topic that has yet to be thoroughly studied and requires more work. For example, one may ask if this was just a threat or if such excommunications were actually enacted. 
that took place and were continuously redefined. ${ }^{9}$ It follows that oftentimes individuals would need to choose between their own personal interests and those of the community.10

How then did Jews determine the paths they chose to make a living? How did they choose with whom to do business? Using a communal perspective, many scholars have assumed that Jews preferred to interact with other Jews and that partnerships with Christians were also organized by communal agreements. One such agreement was the ma'arufia, a term that reflects a particular type of Jewish-Christian patron-client relationship. ${ }^{11}$ Appearing frequently in early communal ordinances from the period prior to and immediately following the First Crusade, the term ma'arufia is often found in ordinances that sought to regulate relations between Jews and Christians in order to reduce competition between Jews. They thus declared that once a specific Christian had a relationship with a certain Jew, other Jews should not seek to take over this client. In light of the familiarity with these ordinances, many scholars have assumed such relationships were the norm throughout the medieval period.

However, the articles in this collection, which focus on the thirteenth and fourteenth centuries, indicate that there is a need to reassess this assumption, and that we should be wary of extrapolating earlier behaviors and attitudes onto this later period. The authors present a variety of different types of partnerships initiated by individuals, and do not contain evidence of ma'arufia-like

9 Some of the earliest privileges, such as, for example, the one issued by Louis the Pious in the ninth century, were given to individuals. In contrast, other privileges, for example those of Henry the III and IV of Germany or that issued to the Jews of Speyer by Bishop Rudiger, were given to communities. For these and many other examples, see Julius Aronius, Regesten zur Geschichte der Juden im fränkischen und deutschen Reiche bis zum Jahre 1273 (Berlin: L. Simon, 1902), for example 30-32, \#81, \#82; 41 \#98; 61-62, \#144, $68-70, \#_{168} ; 74-75$, \#170, \#171; 139-42, \#315 and others. In general, my impression is that during the twelfth and thirteenth centuries more privileges were given to communities than individuals. This does not mean that individuals did not also negotiate in different ways. After the Black Death in Germany and throughout the fourteenth century in northern France, privileges were again negotiated with individuals. See for example: Michael Schlachter, "Iudei ... reversi sunt: Zur Reorganisation jüdischen Lebens in Aschkenas nach 1350," in The Jews of Europe around 1400: Disruption, Crisis, and Resilience, ed. Christoph Cluse and Lukas Clemens (Wiesbaden: Harrassowitz Verlag, 2018), 31-54.

10 See an example of this sort, Judah b. Samuel, Sefer Hasidim (Parma), ed. Judah Wistinetski (Frankfurt: M. A. Wahrmann, 1924), \#1292 [Hebrew] and MS JTs Boesky 45, fol. 143v-144r, \#519 [Hebrew].

11 About ma'arufia, see many early responsa that refer to it, especially the chapter on monopolies: Irving A. Agus, The Heroic Age of Franco-German Jewry: The Jews of Germany and France of the Tenth and Eleventh Centuries, the Pioneers and Builders of Town-Life, Town-Government, and Institutions (New York: Yeshiva University Press, 1969), 1: 192, 195-97, 210-16, 227-28, 232-33; Shlomo Eidelberg, “'Ma'arufia' in Rabbenu Gershom's Responsa," Historia Judaica 15 (1953): 59-66. 
relationships. ${ }^{12}$ In some cases, partnerships between Jews and Christians even went against the interests of the communities to which these Jews belonged. Opening the collection, Nureet Dermer's article focuses on a singular event that took place in Paris in 1293, when two Parisian Jews were caught smuggling merchandise together with the Abbot of St. Denis. Their detention provoked a brawl on the street that resulted in a court record. In this case, Jews and Christians partnered in illegal business. Andreas Lehnertz's article also features a partnership between a Jew and a Christian in Erfurt that led to the deception of Jews throughout the Holy Roman Empire, selling them "damaged" shofarot (horns) for ritual use. Such joint ventures were not only common in connection with sinister activities. Both Aviya Doron and Daniel Lord Smail also highlight the frequency with which transactions took place between Jews and Christians and the different ways they negotiated trust and mutual dependency.

The different cases discussed in these articles, whether the singular cases examined by Dermer and Lehnertz or the large numbers of records examined by Smail and Doron, present another question that has yet to be seriously investigated: to what extent were partnerships between Jews and non-Jews common, and were they viewed by Jews and Christians alike much like partnerships between two Jews or two Christians? How did Jews balance their individual needs and those of the community to which they belonged and to what extent did communal leaders, religious or lay, have the power to enforce fiscal demands? ${ }^{13}$ In what ways were Jews like their neighbors and how was their conduct specifically related to their being Jews? How did their religious affiliation impact on the way they conducted business? Daniel Lord Smail investigates inventories of Jewish homes and extends this question, asking not just how different the ways Jews conducted business was from their Christian neighbors but also to what extent the material goods found in their homes

12 Later sources call Christian partners shutaf, meaning partner. The word shutaf does not imply a regular and continuous relationship in the way the ma'aruf or ma'arufia did. In the earlier sources the word ma'aruf implies a relationship that was a commercial monopoly a specific Jew had with a specific Christian. Such a relationship meant that only this Jew could do business with this Christian. However, Sefer Hasidim, for example, seems to interchange the words shutaf (partner) and ma'arufia).

13 For a survey of European economy, see M. M. Postan, E. E. Rich, and Edward Miller, The Cambridge Economic History of Europe. Vol. 3 (Cambridge: Cambridge University Press, 1963); Robert S. (Robert Sabatino) Lopez, The Commercial Revolution of the Middle Ages: 950-1350 (Cambridge: Cambridge University Press, 1976); Peter Spufford, Money and Its Use in Medieval Europe (Cambridge: Cambridge University Press, 1988); Joel Kaye, Economy and Nature in the Fourteenth Century: Money, Market Exchange and the Emergence of Scientific Thought (Cambridge: Cambridge University Press, 200o); Gerhard Fouquet and Hans-Jörg Gilomen, eds., Netzwerke im europäischen Handel des Mittelalters (Ostfildern: J. Thorbecke, 2010); Martha C. Howell, Commerce before Capitalism in Europe, 1300-1600 (Cambridge: Cambridge University Press, 2010). 
were similar and/or different. His analysis suggests that material culture was an important engine of interaction.

The cases presented in some of these articles reveal that the business interests of individual Jews were at time at odds with the mandates of the community or local rulers, but, in all instances, were in dialogue with local norms and institutions. It is in this context that it becomes more complicated to follow the paths chosen by individuals and those prescribed or directed by the community leaders or local authorities. Dean Irwin studies an acknowledgment of debt produced in Canterbury in 1264 that documents a loan from Maruna, daughter of Vives, to one John son of Nicholas of Finglesham (Kent). Tracing the movement of this document from place to place and hand to hand, Irwin is able to draw a picture of the centralized system of "Archae," which were chests used in England to centralize and control the economic interactions related to credit between Jews and Christians. He also provides an in-depth analysis of the political upheaval that occurred in the late thirteenth century in England and identifies the ways this upheaval impacted Jews and their place in the credit market of the period. In doing so, he highlights the extent to which even a single simple loan was deeply entrenched in royal, local, and interreligious politics.

In Dermer's case, through the prism of one particular microhistory, she investigates the ways Jews contended with the challenges they faced in their daily economic interactions and underlines the extent to which even when caught together in the same act, consequences differed for Jews and Christians. In this particular case, in which two specific individuals were caught evading local tariff rules, the terms used when discussing their plight, specifically the term "foreigner," allow Dermer to outline the changing perceptions of Jews as foreigners and the process of alienation and marginalization that eventually resulted in the repeated expulsions of the Jews from northern France during the fourteenth century.

Taken together these articles demonstrate that in the thirteenth, fourteenth, and fifteenth centuries, multiple forms of business relationships existed between Jews and Jews and between Jews and Christians. Some of these interactions increased internal competition and set members of the community against each other, as in the case examined by Lehnertz in which the rabbi who authored the letter he examines sought to promote one member of his community at the expense of another. The many different types of alliances that emerge from these studies call for a reassessment of our understanding of how medieval European Jews chose their business partners and the wide variety of considerations that were part of this process. They also demonstrate the extent to which individual considerations played an important role alongside communal dictates and constraints. 
Jews were part of a tangled web of relationships that included their families, communities, and local and regional environments. The records that report these relationships often reduce specific women and men into anonymous actors - into a "Jew" and a "Christian." However, behind these anonymous figures were individuals, honest and dishonest, irritable and temperate. In some cases, individual Jews preferred Christian business partners either precisely because they did not share the same communal obligations or for reasons that had to do with personal chemistry or shared interests. In other cases, partnerships between Jews were felt to be a more fortuitous route. ${ }^{14}$

Much of the research to date has assumed that the role of religious identity was paramount to all other considerations, and, of course, at times it was. Alexandra Sapoznik's article, for example, shows how religious difference itself made lines of commerce possible. She focuses on the place of honey and wax in the different religious cultures of Islam and Christianity and then describes the prolific trade in Barbary wax, which was shipped to Europe from North Africa. Wax, especially beeswax, was much in demand in Christian Europe, as wax was a central ingredient in the innumerable candles that were lit in the churches as part of devotional rituals. Muslims, on the other hand, raised their bees for honey and were more than happy to sell off what they considered a useless by-product. In this trade it was the Jewish and/or converso merchants who often played the role of middlemen. Sapoznik posits that this may have been related to the quandaries posed by trade in a commodity so obviously meant for liturgical purposes. She demonstrates how these Jewish or converso traders were deeply embedded in their commercial networks, and well-positioned geographically, culturally, linguistically, and economically to facilitate between the Christian and Muslim worlds. She also illustrates how conversos kept up the old networks they had before conversion. In contrast, other essays problematize the assumption that religion was always a factor in business interactions, most emphatically in the case study examined by Lehnertz.

The emphasis on religion in prior research was often coupled with the assumption that medieval Jews had one central role in the medieval economy - that of money lenders - which was accompanied by theological undertones and implications. This profession made Jews the object of much hate and distrust, positioning them as a theological "other," as a result of the biblical

14 Francesca Trivellato, The Familiarity of Strangers: The Sephardic Diaspora, Livorno, and Cross-Cultural Trade in the Early Modern Period (New Haven: Yale University Press, 20o9); Francesca Trivellato, Leor Halevi, and Cátia Antunes, Religion and Trade: Cross-Cultural Exchanges in World History, 1000-1900 (Oxford: Oxford University Press, 2014). 
interdiction against lending with interest. ${ }^{15}$ Following these foci, an underlying conviction of much research has been that partnerships between Jews and Christians served functional purposes and were, at best, arrangements of necessity rather than choice. Put differently, the main role of the Jews was to provide needed funds and Christians turned to them only as a last resort, rather than as part of ongoing commerce. ${ }^{16}$

This approach had two important implications: The assumption that Jews preferred to work with other Jews, and by extension the implied connection between all Jews, wherever they were, especially when considering preCrusade Europe, evoked almost mythical accounts of Jewish networks that stretched across oceans. One idea that has been refuted has to do with Jews as powerful international merchants. Recent work, first and foremost that of Michael Toch, has sought to establish that the majority of Jews were active in a defined region at most, and never, even before the First Crusade, controlled or had a monopoly on major trade routes. Toch's work, summarizing much of recent research concerning all of medieval Europe, has demonstrated how Jews were active in demarcated regions, based on the agreements in place with local powers. ${ }^{17}$

The idea that Jews preferred business partnerships with other Jews was reinforced in studies of the period after the First Crusade. Explained as resulting from the animosity against Jews, many scholars assume that Jews and Christians interacted only when absolutely necessary. This assumption led to a focus in research on ongoing tensions between Jewish lenders and the

15 Toni Oelsner, "The Place of the Jews in Economic History as Viewed by German Scholars: A Critical-Comparative Analysis," The Leo Baeck Institute Year Book 7.1 (1962): 183-212; Giacomo Todeschini, "Christian Perceptions of Jewish Economic Activity in the Middle Ages," in Wirtschaftsgeschichte der mittelalterlichen Juden: Fragen und Einschätzungen, ed. Michael Toch (Munich: R. Oldenbourg, 2016), 1-16; Rowan W. Dorin, "Once the Jews Have Been Expelled: Intent and Interpretation in Late Medieval Canon Law," Law and History Review 34 (2016): 335-62; Anna Sapir Abulafia, Christian-Jewish Relations, 1000-1300:Jews in the Service of Medieval Christendom (New York; London: Routledge, Taylor \& Francis Group, 2014), 37-108; Kenneth R. Stow, "Papal and Royal Attitudes toward Jewish Lending in the Thirteenth Century," AJS Review 6 (1981): 161-84; Rowan W. Dorin, "L'expulsion des usuriers lombards hors de France à la fin du XIII" siècle," Hypotheses 17 (2014): 153-62.

16 Giacomo Todeschini, "Jewish Usurers, the Blood Libel and Second Hand Economy", in The Medieval Roots of Antisemitism: Continuities and Discontinuities from the Middle Ages to the Present Day, ed. Jonathan Adams and Cordelia Hess (New York; London: Routledge, 2018), 341-45; Christian Scholl, "Jews and Christians", in Kypta, Bruch, and Skambraks, Methods in Premodern Economic History, 163-68.

17 Michael Toch, The Economic History of European Jews: Late Antiquity and Early Middle Ages (Leiden: Brill, 2013), 193-205. See also Jessica Goldberg, Trade and Institutions in the Medieval Mediterranean: The Geniza Merchants and their Business World (Cambridge: Cambridge University Press, 2012). 
Christians who sought loans and resulted in a lack of attention to other Jewish economic activities. However, recent studies on Jewish money lending have demonstrated that the stereotype of the Jewish money lender in fact only developed in early modern and modern literature. ${ }^{18}$ As for the medieval period, although Jews certainly were money lenders, they were not the only group engaging in this practice, ${ }^{19}$ since Jews lent money to Jews and Christians, and Christians lent money to Christians and to Jews. The recognition that money was lent and credit was given continuously by all medieval Europeans and the understanding that Jews participated in the economy in a number of different ways, revitalizes the importance of understanding the role of the Jews in European economic history at large. ${ }^{20}$

Half of the articles in this volume discuss money lending activities, yet they illuminate these activities with new emphases. Dean Irwin's article remains closest to traditional studies of Jewish-Christian interaction, yet he highlights ritual procedures and especially the importance of gender in this context. Daniel Lord Smail's article illustrates the centrality of money lending in Jewish activities that were documented by notaries but also suggests a new angle for

18 Francesca Trivellato, The Promise and Peril of Credit: What a Forgotten Legend about Jews and Finance Tells Us about the Making of European Commercial Society (Princeton: Princeton University Press, 2019); Julie Mell, The Myth of the Medieval Jewish Moneylender, 2 vols. (Cham: Palgrave Macmillan, 2017-2018) One volume of Mell's book reviews historiography and the other provides medieval examples.

19 See Jacques Labrot, Affairistes et usuriers au Moyen âge, L'histoire (Cahors: la Louve éd, 2008); Giulia Scarcia, "La typologie des actes de crédit. Les 'mutua' des 'Lombards' dans les registres notariés du XIV e siècle," in Notaires et crédit dans l'Occident méditerranéen médiéval (Rome: École Française de Rome, 2004), https://doi.org/10.140o/38494; Rowan Dorin, "Banishing Usury: The Expulsion of Foreign Moneylenders in Medieval Europe, 1200-1450" (Ph.D. diss., Harvard University, 2016).

20 See $n .16$ above. The tax lists from Paris point to a variety of professions as well, see for example, David Herlihy, Opera Muliebria: Women and Work in Medieval Europe (New York: McGraw-Hill, 199o). Sharon A. Farmer, The Silk Industries of Medieval Paris: Artisanal Migration, Technological Innovation, and Gendered Experience, (Philadelphia: University of Pennsylvania Press, 2017) for professions related to the silk industry; Nureet Dermer, "The Jews in the Tax Lists (Taille) of Late 13th Century Paris: The Socio-Economic and Cultural Lives of Jewish Men and Women in Christian Neighborhoods" (M.A. Thesis, The Hebrew University of Jerusalem, 2018) where she also notes teachers, tailors, barbers and silversmiths. See also Shatzmiller, Cultural Exchange, 141-57; Michael Toch, "Geldleiher und Sonst Nichts? Zur wirtschaftlichen Tätigkeit der Juden im deutschen Sprachraum des Spätmittelalters," Tel Aviver Jahrbuch für Deutsche Geschichte 22 (1993): 117-26; Michael Toch, "Economic Activities of German Jews in the Middle Ages," in Wirtschaftsgeschichte der mittelalterlichen Juden: Fragen und Einschätzungen, ed. Michael Toch (Munich: R. Oldenbourg, 2016), 181-210. We look forward to Andreas Lehnertz's forthcoming study of Jews and crafts in the Middle Ages. 
assessing the centrality of money lending in these interactions. Smail notes the everyday functions some of these debts reveal. For example, some debts hint at money exchanged to obtain everyday needs, such as grain for bread. Grain arrived by ship to Marseille and was taken to the millers, who were Christians, and baked in ovens, often owned by Christians. Interactions such as these, requiring daily contact between Jews and Christians, were far more frequent than money lending. Other commodities required similar activities: barley, figs, nuts, cheeses, fabric, thread or yarn, and more. Although constant interaction between Jews and Christians, both social and economic, would have been necessary to procure these everyday items, these mundane activities have hardly been taken into consideration to date when studying Jewish life in medieval Europe. Adding their frequency to the interactions for which we have more documentation, is a desideratum.

Aviya Doron's article studies pledges, focusing on one particular kind of pawn - horses. Horses appear as pawns in a wide variety of texts that discuss Jewish-Christian loans, including rabbinic responses, Christian legal cases, municipal laws, and even the illustrations of the Sachsenspiegel, yet their centrality has tended to go unnoticed. Using court records from Frankfurt she also demonstrates that this was a niche business undertaken only by particular men and women, sometimes in partnership with Christians who helped care for the animals. Doron's article shows how a phenomenon that appears in numerous disparate sources can be identified and examined, and notes how risk, specialization, and religion played a role in credit relations and how these credit relations provide a window on additional activities that were not necessarily related to money lending, such as caring for animals or shared professions that required ongoing cooperation.

Shared professions are noted in other articles as well: Andreas Lehnertz's article centers around an event that took place over a century later in Erfurt, Germany. In 1421, two men, a Jew and a Christian, partnered together to manufacture and sell shofarot, the horns used by Jewish communities as part of their Rosh Hashana (Jewish New Year) ritual. As in the case researched by Dermer, this Christian-Jewish partnership was not related to money lending but was rather a professional partnership consisting of a shared craft, over which, according to Lehnertz, they held a monopoly in the area. The shofarot were not, however, manufactured in accordance with rabbinic guidelines and the two were exposed by the local rabbi in Erfurt, who, not incidentally, also supported a different Jewish craftsman who had recently learned the trade.

Shared professions lead to the topic of shared space. When Jews and Christians worked together, they did so in joint premises. This issue is connected to a topic that has been reassessed over the past years, the extent to 
which Jews and Christians shared space far more than assumed. The local courts are a case in point. An assumption in previous research, especially in English and Hebrew scholarship, was that Jews avoided the local non-Jewish courts and institutions as much as possible, preferring to resolve their problems internally, within the communities. Although this idea has been clearly refuted in German literature since the beginning of the twentieth century, ${ }^{21}$ as well as in a number of French studies, ${ }^{22}$ it has not been sufficiently incorporated into evaluations of medieval Jewish economic life more generally. The persistence of this idea alongside other "myths" or stereotypes has shaped research to date. ${ }^{23}$

Recent research on medieval systems of justice has sought to better understand Jewish activities in local courts of different kinds. Following archival discoveries of Jewish presence in multiple non-Jewish local courts, these studies have sought to determine the extent to which Jews in fact made use of the infrastructures of local institutions, such as notaries and the various types of courts as well as the local markets and trades, by examining hundreds of cases involving Jews that occurred in specific locations. ${ }^{24}$ Aviya Doron follows the

21 For example Isidor Kracauer, Urkundenbuch Zur Geschichte Der Juden in Frankfurt Am Main von 1150-1400 (Frankfurt am Main: Kauffmann, 1911); Moritz Stern, Die Israelitische Bevölkerung Der Deutschen Städte: Ein Beitrag Zur Deutschen Städtegeschichte, Mit Benutzung Archivalischer Quellen (Frankfurt am Main: Kauffmann, 189o); Moritz Stern and Robert Höniger, Das judenschreinsbuch Der Laurenzpfarre zu Köln (Berlin: L. Simion, 1888).

22 Joseph Shatzmiller, "La solidarité juive au Moyen Age et ses limites : Histoire et contrehistoire," in Minorités et marginaux en France Méridionale et dans la péninsule Ibérique (VII-XVIII ${ }^{e}$ siècles), ed. Pierre Tucoo-Chala and Martine Lambert-Gorges (Paris: Éditions du CNRS, 1986), 413-427.

23 This too is related to genre. The significant work done on medieval responses over the past several decades, from Jacob Katz and onward, has privileged Hebrew material that tended to support a more separatist mode of assessing the Jewish past. And too, the impact of specialization should not be minimized. Scholars who study response literature in Hebrew tend to be unfamiliar with literature in other languages and those who study Latin or vernacular texts tend to lack fluency with literature in Hebrew. For an exception, see Rena N. Lauer, Colonial Justice and the Jews of Venetian Crete (Philadelphia: University of Pennsylvania Press, 2019).

24 Rebecca Lynn Winer, Women, Wealth, and Community in Perpignan, c.1250-1300:Christians, Jews, and Enslaved Muslims in a Medieval Mediterranean Town (Aldershot, Hants, England: Aldershot: Ashgate, 2006); Elka Klein, Jews, Christian Society, \& Royal Power in Medieval Barcelona, History, Languages, and Cultures of the Spanish and Portuguese Worlds (Ann Arbor: The University of Michigan Press, 2006); Daniel Lord Smail, The Consumption of Justice: Emotions, Publicity, and Legal Culture in Marseille, 1264-1423 (Ithaca, NY: Cornell University Press, 2003); Daniel Lord Smail, Legal Plunder: Households and Debt Collection in Late Medieval Europe (Cambridge, Mass.: Harvard University Press, 2016); David Schnur, Die Juden in Frankfurt am Main und in der Wetterau im Mittelalter: Christlich-jüdische 
documentation of hundreds of pledges of pawns received in return for money lent to Christians by Jews in courts and demonstrates the frequency with which Jews resorted to these recourses. Nureet Dermer's discussion of an individual caught and tried in court is a further indication of this ubiquity of these types of interactions, while Dean Irwin's study provides a glimpse of a system created to deal specifically with the Jews and shows its alignment with other practices of the time.

\section{$3 \quad$ Sources and Genre}

An additional factor that has shaped research to date concerning Jewish economic activities is the type of sources used and the ways that genre dictated understandings of both Jews and the economy. Thus, a focus on theological tractates led to an emphasis on religious difference and also to the portrayal of Jews as money lenders, as usury was often a central concern in these texts. ${ }^{25}$ Similarly, scholars who focused on images of Jews depicted in the market place or doing business elsewhere, applied symbolic interpretation to this art, in accordance with the producers and manuscripts within which it was found, again underlining theology. ${ }^{26}$ Those who studied privileges found evidence for tolerance or intolerance depending on time and place, but also favored a communal rather than an individual approach. And those studying court cases often sought to determine the place of Jews qua Jews rather than asking how Jews fit or did not fit into general patterns in the city. This theological and communal-based approach was reinforced by studies of court cases in which the emphasis was on credit and loans, because debts were often registered and claimed in the local courts and by notaries. ${ }^{27}$ Since many of the surviving records provide evidence for credit transactions, this genre of sources highlights money lending, echoing the theological sources. ${ }^{28}$

Beziehungen, Gemeinden, Recht und Wirtschaft von den Anfängen bis um 1400 (Wiesbaden: Komission für die Geschichte der Juden in Hessen, 2017).

25 We look forward to Anna Sapir Abulafia's study of such theological tractates and their transmission. See Giacomo Todeschini, "Franciscan Economics and Jews in the Middle Ages: From a Theological to an Economic Lexicon," in Friars and Jews in the Middle Ages and Renaissance, ed. Steven J. McMichael and Susen E. Reynolds (Leiden: Brill, 2004), 99-117.

26 Sara Lipton, Images of Intolerance: The Representation of Jews and Judaism in the Bible Moralisée (Berkeley: University of California Press, 1999).

27 See the articles by Aviya Doron and Dan Smail in this issue.

28 Regarding the impact of genre see note 24 above. For some exceptions, see Joseph Shatzmiller, Recherches sur la communaute juive de Manosque au Moyen Age, 1241-1329 (Paris: Paris: Mouton, 1973); Rena N. Lauer, Colonial Justice. 
One way to balance these emphases is the analysis of multiple genres rather than one type of source. This is most evident in Aviya Doron's article, which encompasses a wide range of sources in order to better understand the use of horses as pawns. While she highlights credit and money lending activities related to these pawns, the wide range of sources helps highlight the other roles Jews played within the economy. Smail's analysis of inventories frames objects owned by Jews as personal belongings rather than as objects given or received as pledges.

Another way to balance the specific emphases of genre has to do with the growing importance of local history in many recent studies, including those in this volume that make the possibility of generalization less likely. ${ }^{29}$ Each region had its own forms of governance and its own particular set of circumstances. In England, as in northern France under the Capetians, a more centralized system was in place, as is evident in Dean Irwin's article, whereas in the Holy Roman Empire a non-centralized system was prevalent. ${ }^{30}$ In addition, many cities and towns had their own unique structures and institutions. Jews, like their neighbors, knew the limits and possibilities of these various alternatives. Thus, an increasingly nuanced picture of Jewish life and their relationships between Jews and their Christian neighbors during this period is being constructed. The proliferation of archival materials in the fourteenth century that provides a view of the activities of hundreds of people, Jews and Christians, allows general trends to be outlined alongside specific occurrences, as in the work of Dermer, Doron, Sapoznik, and Smail within this volume.

Taken together these articles demonstrate how integrated the Jews were in the different economies of which they were part, and the extent to which they were familiar with, had recourse to, and made use of local institutions for their quotidian dealings. They provide a broad geographical and temporal range, from England in the west to Erfurt and Frankfurt in the east and the Maghreb in the south, over a period of approximately two hundred years. Each case study offers a glimpse into the ways different systems intersected and the extent to

29 See for example the works of Schnur, Die Juden in Frankfurt; Lämmerhirt, Juden in den wettinischen Herrschaftsgebieten; Christoph Cluse, "Studien zur Geschichte der Juden in den mittelalterlichen Niederlanden" (Hannover: Hahn, 2000); Judith Olszowy-Schlanger, Hebrew and Hebrew-Latin Charters and Tallies from Medieval England (Turnhout: Brepols, 2015); Angela Möschter, Juden im venezianischen Treviso (1389-1509) (Hannover: Hahn, 2008). Each of these studies focuses on a specific region and it is hard to generalize about other areas based on the specificity.

30 See Robert C. Stacey, Royal Taxation and the Social Structure of Medieval Anglo-Jewry: The Tallages of 1239-1242, Hebrew Union College Annual 56 (1985):175-249; Elizabeth A. R. Brown, Politics and Institutions in Capetian France (New York: Routledge, 2018). 
which Jews were both similar to and different from their neighbors. Because Jews and Christians used the same institutions and shared the same practices, a comparison between the various ways in which each accessed these institutions, (such as Smail's examination of Marseille documents, Doron's study of the court registers from Frankfurt, Dermer's use of records from the parloire of Paris, or Sapoznik's examination of tax records), can help clarify which behaviors were characteristic of Jews and which of Christians, and which practices were used by members of both religions.

The articles by Doron and Lehnertz, which make use of evidence stemming from both in and outside of the Jewish community, provide a glimpse of the different ways economic situations played out in each of these spaces. Within the community an additional legal system came into play, that of halakhah, and other communal tools, such as excommunication, as discussed in the opening of this article. Comparing the ways economic interactions were reported in internal communal literature on the one hand, and archival and court documents on the other, also allows a multi-vocal appreciation of the events being described, broadening the types of sources used for such analysis. We believe that this collection of essays, and the methods adopted by the authors in their focus on daily interactions between Jews and Christians, present a nuanced and sophisticated conception of the complexities of Jewish economic activity in medieval Europe.

This collection was produced under the auspices of the Beyond the Elite: Jewish Daily Life in the Middle Ages research team. ${ }^{31}$ Our work, as a group, has been geared towards complicating narratives of medieval Jewish-Christian relations and social history by including the mundane and quotidian, rather than just the extreme situations, within the historical narrative. We present this foray into economic social history as part of our ongoing contribution to the field. ${ }^{32}$

\author{
Elisheva Baumgarten | ORCID: 0000-0002-1735-6738 \\ Prof. Yitzchak Becker Chair in Jewish Studies, Dept. of Jewish History and \\ Contemporary Jewry and Dept. of History, Faculty of Humanities, \\ Jerusalem, Israel \\ Elisheva.Baumgarten@mail.huji.ac.il
}

31 https://beyond-the-elite.huji.ac.il/.

$3^{2}$ See our recent publications, among them I will note a volume on medieval Jewish space in Jewish Studies Quarterly 28, vols. 3-4 (2021); and Elisheva Baumgarten and Ido Noy, eds., In and Out, Between and Beyond Jewish Daily Life in Medieval Europe (Jerusalem: The Max and Iris Stern Gallery, Hebrew University of Jerusalem, 2021). 